\title{
Synthesis of biomimetic precursors of isovelleral analogues
}

\author{
Daniel Röme, Erwan Arzel, Martin Johansson, and Olov Sterner* \\ Division of Organic Chemistry, Lund University, P.O. Box 124, S-221 00 Lund, Sweden \\ E-mail: Olov.Sterner@organic.lu.se
}

Dedicated to Prof. Torbjörn Norin on the occasion of his 75th birthday

\begin{abstract}
Based on how the mushroom Lactarius vellereus converts an inactive precursor into the cytotoxic dialdehyde isovelleral (1) via a cyclic enol ether, as part of a binary chemical defense system that protects the fruit bodies against parasites, a synthetic way to obtain analogous dialdehydes masked in the same way has been developed. As isovelleral analogues (e.g. 2 and 3) possess extremely potent cytotoxic activity, but display low selectivity as their biological activity is linked to their reactivity, suitably masked isovelleraloids that are converted to the corresponding dialdehyde under specific conditions, may constitute a way to utilize these potent compounds. Specifically, compounds 4 and 5, biomimetic precursors of the isovelleral analogues 2 and 3, but trapped as the stable methyl acetals, have been prepared.
\end{abstract}

Keywords: Biomimetic, isovelleral analogues, cytotoxic dialdehyde, methyl acetal

\section{Introduction}

In the fruit bodies of the pungent Lactarius species, an ingenious binary chemical defense system has evolved. ${ }^{1}$ It is based on the rapid (seconds) enzymatic conversion of inactive precursors to pungent and antibiotic sesquiterpenes with an unsaturated 1,4-dialdehyde moiety, as a response to physical injury to the fruit body. For example, in fruit bodies of Lactarius vellereus stearoylvelutinal (6c) is converted to the dialdehyde isovelleral (1) (see Scheme 1). The conversion is so fast that $\mathbf{1}$ actually was believed to be a normal metabolite of $L$. vellereus fruit bodies, however, the investigation of specimens frozen in liquid nitrogen at their natural habitat showed that the truly intact mushroom does not contain $\mathbf{1}$. It is a binary chemical weapon in the sense that the precursor $\mathbf{6 c}$ is present as an emulsion in special pressurized hyphae in the intact fruit body, and only brought in contact with the enzymes responsible for the conversion by an injury that disrupts these hyphae. The dialdehydes are consequently only formed at the site of an injury, not in the entire mushroom. They not only deter parasites from consuming the fruit 
bodies, but also inhibit infections of the fruit body caused by bacteria and other fungi. In a second slower step, that will take minutes, the dialdehydes are reduced (isovelleral (1) to isovellerol (7)) to form less active compounds in the injured tissue, ensuring that the time the fruit body is exposed to the reactive dialdehyde is limited.

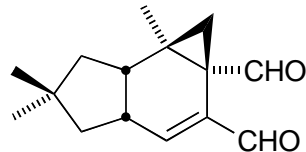

1<smiles>O=CC1=CCC[C@@H]2C[C@]12C=O</smiles>

2

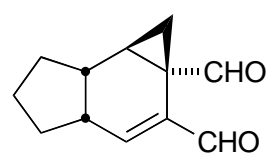

3<smiles>COC1OC=C2[C@@H](O)CC[C@@H]3C[C@@]213</smiles>

4<smiles>COC1OC=C2[C@@H](O)C3CCCC3[C@H]3C[C@]213</smiles>

5

\section{Figure 1}

The mechanism for the conversion of stearoylvelutinal (6c) to isovelleral (1) in L. vellereus has been shown to proceed via ester hydrolysis to give the hemiacetal velutinal (6a). ${ }^{2}$ This is followed by an enzymatic $\beta$-elimination of the epoxide in $\mathbf{6 a}$ to yield the proposed intermediate 8a, that spontaneously would be converted to isovelleral (1) ${ }^{3,4}$ The formation of $\mathbf{8 a}$, which should be highly unstable, was never demonstrated, but feeding the injured mushroom tissue methylvelutinal (6b), obtained by solvolysis of $\mathbf{6 c}$ in methanol, resulted in the formation of $\mathbf{8 b}$, which could be isolated and characterized.

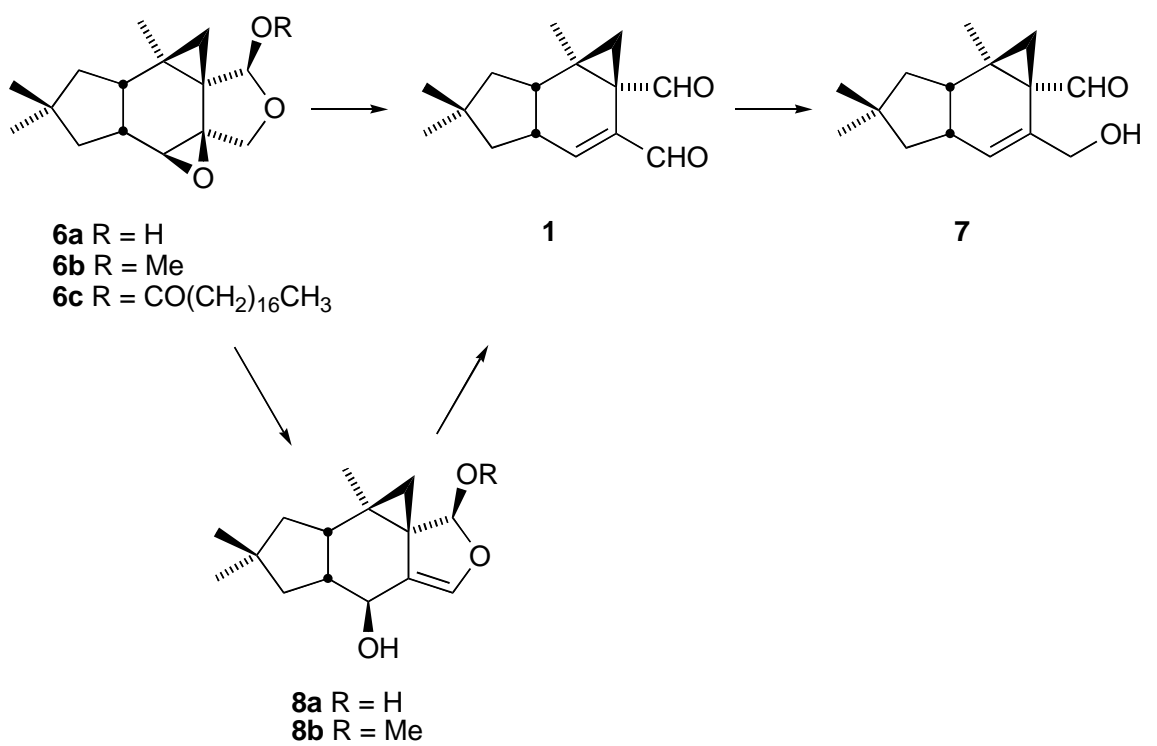

\section{Scheme 1}


During an investigation of QSARs of the isovelleraloids, ${ }^{5}$ the synthetic analogues $2^{6}$ and $\mathbf{3}^{7}$ (see Figure 1) were prepared and shown to be even more potent than isovelleral (1). Especially 3, which cytotoxicity towards tumor cells is approximately 10 times that of 1 . $^{7}$ However, the general reactivity of the unsaturated dialdehydes prohibits any practical uses, as they will be toxic to all cells and tissues. Nonetheless, utilizing a pro-drug strategy whereby by the reactive functionality is protected in a way that a) makes it is less reactive and b) is deprotected by the conditions (chemical or enzymatical) encountered in certain cells (e.g. tumor cells) or organisms (e.g. pests), the selectivity could increase dramatically. For example, tumor cells are known to be more acidic compared to normal cells due to accelerated metabolism, and may overexpress certain enzymes significantly. As we have noted that the methyl acetal $\mathbf{8 b}$ is rapidly hydrolysed to isovelleral in the presence of traces of acid, we decided to prepare the corresponding derivatives of the two isovelleral analogues 2 and 3, the cyclic enol methyl acetals 4 and 5 (see Figure 1).

\section{Results and Discussion}

The syntheses of acetals 4 and 5 are presented in Schemes 2 and 3. The oxidation of $\beta$-keto ester 9 to the corresponding $\alpha, \beta$-unsaturated keto ester 10 was carried out with DDQ in good yield, ${ }^{8}$ and a stereoselective Corey-Chaykovsky cyclopropantion of $\mathbf{1 0}$ in $\mathrm{DMF}^{9}$ followed by a standard "salt-free" Wittig reaction ${ }^{10}$ afforded 11. Alkene 11 was epoxidized with $m-\mathrm{CPBA}^{10}$ in the presence of $\mathrm{NaHCO}_{3}$, the epoxide was not isolated but was opened directly by the addition of catalytic amount of $p$ - $\mathrm{TsOH}$ in $\mathrm{CHCl}_{3}$ which also effected the formation of the lactone ring to yield 12. ${ }^{10}$ The lactone was reduced to the corresponding lactol with DIBAL-H in toluene, ${ }^{11}$ the resulting hemiacetal was converted to the more stable methyl acetal with a catalytic amount of $p$ $\mathrm{TsOH}$ in pentane/MeOH (9:1), where after the allylic lactol was stereoselectively epoxidized with dimethyldioxirane (DMDO) in acetone ${ }^{11,12}$ yielding 13. The final regioselective epoxide opening was carried out with an excess of diisopropyl amine and n-BuLi (1:1), which produced the desired regioisomer 4.

The synthesis of 5 followed the same procedure, the $\alpha, \beta$-unsaturated $\beta$-keto ester $\mathbf{1 4}^{7}$ was cyclopropanated using the same protocol as for $\mathbf{1 0}$ and was immediately subjected to Wittig conditions to give 16. The epoxidation of 16 was carried out with DMDO in acetone ${ }^{8}$ at $0^{\circ} \mathrm{C}$, and the resulting epoxide was opened in situ to yield the lactone $\mathbf{1 7}$ by addition of a catalytic amount of $p$-TsOH. 17 was subsequently reduced with DIBAL-H and transformed to the methyl-acetal 18, which was epoxidized with DMDO and then opened to 5 by an excess of diisopropyl amine and $t$-BuLi (1:1.3) in THF. ${ }^{6,13}$ Note that the last step of both Scheme 2 and 3 is sensitive to the relative amounts of diisopropyl amine and organolithium reagent $(t-\mathrm{BuLi})$, changing the reported relationship result in mixtures of regioisomers. 

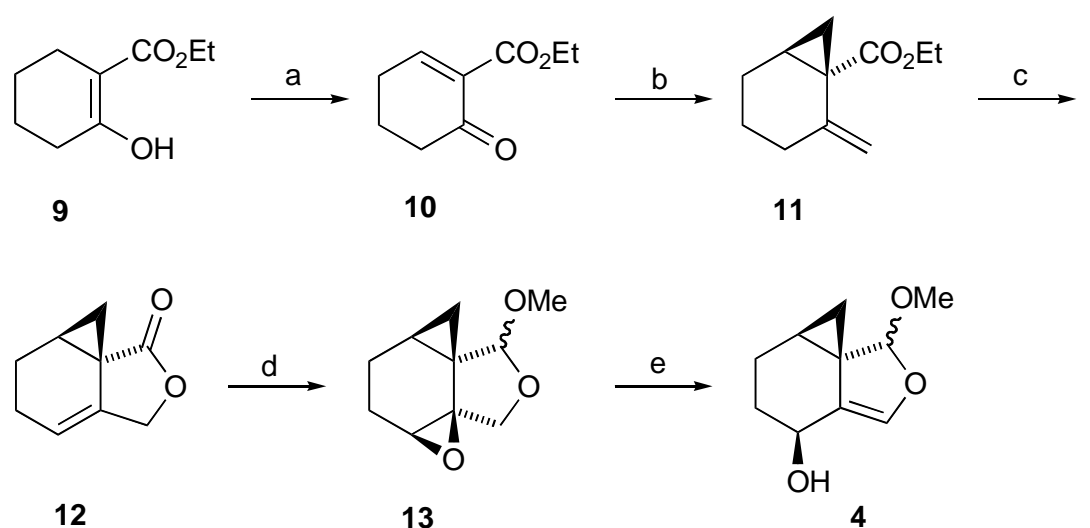

Scheme 2. Reaction conditions: (a) DDQ, AcOH, dioxane, rt, 1.75 h (67\%); (b) i) NaH (oil free), $\mathrm{Me}_{3} \mathrm{SOI}$, DMF, $-15^{\circ} \mathrm{C}, 7 \mathrm{~min}$; ii) $\mathrm{NaNH}_{2}, \mathrm{Ph}_{3} \mathrm{PCH}_{2} \mathrm{Br}$, toluene, $\sim 100 \rightarrow 20^{\circ} \mathrm{C}, 1.5 \mathrm{~h}(39 \%, 2$ steps); (c) i) $m$-CPBA, $\mathrm{NaHCO}_{3}, \mathrm{CH}_{2} \mathrm{Cl}_{2}, 0^{\circ} \mathrm{C}, 3 \mathrm{~h}$; ii) $p$ - $\mathrm{TsOH}$ (catalytic), $\mathrm{CHCl}_{3}, \Delta, 3 \mathrm{~h}(43 \%, 2$ steps); (d) i) DIBAL-H, toluene, $-78^{\circ} \mathrm{C}, 3 \mathrm{~h}$; ii) $p$ - $\mathrm{TsOH}$ (catalytic), pentane $/ \mathrm{MeOH}(9: 1), \mathrm{rt}, 10$ min; iii) DMDO, acetone, $0^{\circ} \mathrm{C}, 1 \mathrm{~h}(18 \%, 3$ steps); (e) diisopropyl amine, $n$-BuLi, THF, $4 \mathrm{~h}$ $(60 \%)$.

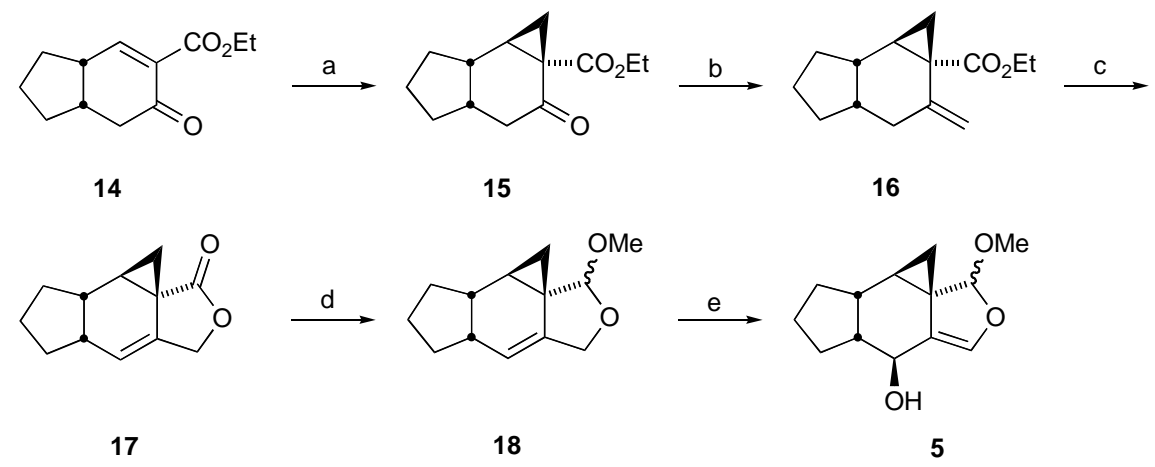

Scheme 3. Reaction conditions: (a) $\mathrm{NaH}$ (oil free), $\mathrm{Me}_{3} \mathrm{SOI}$, DMF, $-15^{\circ} \mathrm{C}, 7 \mathrm{~min}(69 \%)$; (b) $\mathrm{NaNH}_{2}, \mathrm{Ph}_{3} \mathrm{PCH}_{2} \mathrm{Br}$, toluene, $\sim 100 \rightarrow 20^{\circ} \mathrm{C}, 1.5 \mathrm{~h}(69 \%)$; c) i) DMDO, acetone, $0^{\circ} \mathrm{C}, 1 \mathrm{~h}$; ii) $p$ $\mathrm{TsOH}$ (catalytic), $\mathrm{CHCl}_{3}, \Delta, 3 \mathrm{~h}\left(84 \%, 2\right.$ steps); (d) i) DIBAL-H, toluene, $-78^{\circ} \mathrm{C}, 3 \mathrm{~h}$; ii) $p$-TsOH (catalytic), pentane/ $\mathrm{MeOH}(9: 1), \mathrm{rt}, 10 \mathrm{~min}\left(53 \%, 2\right.$ steps); (e) i) $\mathrm{DMDO}$, acetone, $0^{\circ} \mathrm{C}, 1 \mathrm{~h}$; ii) diisopropyl amine, $t$-BuLi, THF, $4 \mathrm{~h}$ (63\%, 2 steps).

The biological activity of the acetals $\mathbf{4}$ and $\mathbf{5}$ will be reported elsewhere.

\section{Acknowledgements}

Financial support from the Swedish Research Council is gratefully acknowledged. 


\section{Experimental Section}

General procedures. Materials were obtained from commercial suppliers and were used without further purification unless otherwise noted. THF and dioxane were dried by refluxing over sodium/benzophenone ketyl immediately prior to use. $\mathrm{CH}_{2} \mathrm{Cl}_{2}$, DMF and $\mathrm{Et}_{3} \mathrm{~N}$ were distilled from $\mathrm{CaH}_{2}$ prior to use. DMSO and $\mathrm{MeOH}$ were dried by sequential drying over $3 \AA$ MS and DMSO was then distilled under reduced pressure prior to use. Toluene was dried with $\mathrm{Al}_{2} \mathrm{O}_{3}$ (neutral, activity I). All moisture and air-sensitive reactions were carried out under an atmosphere of dry nitrogen using oven-dried glassware. Ozonolysis was carried out using an O.S.G. Ozonegenerator NG-5. ESIMS spectra $\left(\mathrm{H}_{3} \mathrm{PO}_{4}\right.$ for calibration and as internal standard) were recorded with a Micromass Q-Tof Micro spectrometer and FABMS spectra were recorded with a Jeol SX102 spectrometer. NMR spectra were recorded with a Bruker ARX 300 spectrometer at $300 \mathrm{MHz}\left({ }^{1} \mathrm{H}\right)$ and at $75 \mathrm{MHz}\left({ }^{13} \mathrm{C}\right)$, Bruker DRX 400 spectrometer at $400 \mathrm{MHz}$ $\left({ }^{1} \mathrm{H}\right)$ and at $100 \mathrm{MHz}\left({ }^{13} \mathrm{C}\right)$ and with a Bruker DRX 500 spectrometer at $500 \mathrm{MHz}\left({ }^{1} \mathrm{H}\right)$ and at $125 \mathrm{MHz}\left({ }^{13} \mathrm{C}\right)$. Chemical shifts are given in ppm relative to TMS using the residual $\mathrm{CHCl}_{3}$ peak in $\mathrm{CDCl}_{3}$ solution as internal standard (7.26 and $77.0 \mathrm{ppm}$, respectively relative to TMS) or using the residual $\mathrm{C}_{6} \mathrm{H}_{6}$ peak in $\mathrm{C}_{6} \mathrm{D}_{6}$ solution (7.16 and $128.06 \mathrm{ppm}$, respectively). Organic extracts were dried over $\mathrm{MgSO}_{4}$. All chromatography was performed on $60 \AA$ 35-70 mm Matrex silica gel (Grace Amicon). TLC analyses were made on Silica Gel $60 \mathrm{~F}_{254}$ (Merck) plates and visualized with anisaldehyde-, Seebach- or permanganate visualization reagent and heating.

Ethyl 2-oxocyclohexenecarboxylate (10). Glacial acetic acid $(5 \mathrm{ml})$ was added to a stirred solution of 9 (4.28 g, $25.17 \mathrm{mmol})$ in dry 1,4-dioxane (137 $\mathrm{ml})$ at room temperature. DDQ (10.00 $\mathrm{g}, 44.05 \mathrm{mmol}$ ) was added, under a blanket of nitrogen, in four portions with intervals of $20 \mathrm{~min}$ to the mixture. The mixture was stirred at room temperature for $45 \mathrm{~min}$, diluted with $\mathrm{CHCl}_{3}(100$ $\mathrm{ml})$ and filtered through celite. The filter-cake was washed with $\mathrm{CHCl}_{3}(3 \times 50 \mathrm{ml})$. The combined filtrate and washings were washed several times with saturated aqueous $\mathrm{NaHCO}_{3}$ until the washings became colorless. The organic fraction was dried, concentrated and chromatographed to give $10(2.60 \mathrm{~g}, 15.50 \mathrm{mmol}, 61.6 \%)$ as a colorless liquid: ${ }^{1} \mathrm{H}$ NMR $(300 \mathrm{MHz}) \delta 7.66(1 \mathrm{H}, \mathrm{t}$, $J=4.1 \mathrm{~Hz}), 4.26(2 \mathrm{H}, \mathrm{q}, J=7.1 \mathrm{~Hz}), 2.52(4 \mathrm{H}, \mathrm{m}), 2.05(2 \mathrm{H}, \mathrm{m}), 1.31(3 \mathrm{H}, \mathrm{t}, J=7.1 \mathrm{~Hz}) ;{ }^{13} \mathrm{C} \mathrm{NMR}$ $\delta$ 194.6, 164.7, 155.7, 133.3, 61.1, 38.7, 26.1, 22.1, 14.1; HRMS (FAB): for $\mathrm{C}_{9} \mathrm{H}_{13} \mathrm{O}_{3}$ calcd $169.0865[\mathrm{M}+\mathrm{H}]^{+}$; found 169.0863 .

Ethyl-2-methylenebicyclo[4.1.0]heptane-1-carboxylate (11). To a flask containing fresh $\mathrm{NaH}$ $(0.30 \mathrm{~g}, 12.52 \mathrm{mmol}$, oil free) and trimethylsulfoxonium iodide (2.76 g, $12.52 \mathrm{mmol})$ was added dry DMF $(50 \mathrm{ml})$ slowly via a syringe and the hydrogen gas generated was ventilated. The mixture was stirred at room temperature until it became clear and all hydride was consumed. The flask was cooled in an acetone-ice bath to $-15^{\circ} \mathrm{C}$ and a solution of $\mathbf{1 0}(2.00 \mathrm{~g}, 11.92 \mathrm{mmol})$ in DMF $(5 \mathrm{ml})$ was added in one portion to the flask via a syringe and the solution turned orange. After 7 minutes TLC indicated complete consumption of starting material 10, and the reaction was quenched by addition of $\mathrm{H}_{2} \mathrm{O}(150 \mathrm{ml})$. The mixture was extracted with $\mathrm{Et}_{2} \mathrm{O}(3 \times 100 \mathrm{ml})$, 
and the combined extracts were washed with large amounts of water, dried, and concentrated to give the crude cyclopropanated product $(1.60 \mathrm{~g})$ as a slightly green oil, which was used directly without further purification. $\mathrm{Ph}_{3} \mathrm{PMeBr}(4.11 \mathrm{~g}, 11.50 \mathrm{mmol})$ was added to a suspension of $\mathrm{NaNH}_{2}(1.14 \mathrm{~g}, 14.70 \mathrm{mmol}, 50 \% \mathrm{w} / \mathrm{w}$ in toluene) in dry toluene $(40 \mathrm{ml})$. The mixture was refluxed for $3 \mathrm{~h}$. The warm clear bright yellow liquid was decanted into a solution of crude cyclopropanated $\beta$-keto ester $(1.05 \mathrm{~g})$ in toluene $(10 \mathrm{ml})$ after the suspension had settled. The reaction was stirred at room temperature for $1 \mathrm{~h}$. (Further ylide was extracted with dry toluene $(15 \mathrm{ml})$ by refluxing the residue of the settled suspension for $1 \mathrm{~h}$, and then poured into the solution of the $\beta$-keto ester). Stirring was continued until the starting material disappeared (determined by TLC). The reaction mixture was washed twice with water, dried and concentrated. Triphenylphosphine oxide was removed as a precipitate, by treatment of the residue twice with warm PE $(25 \mathrm{ml})$. After evaporation of the solvent the crude product was chromatographed to give a colorless oil of 11 (0.58 g, $3.22 \mathrm{mmol}, 39 \%):{ }^{1} \mathrm{H}$ NMR $(300 \mathrm{MHz}) \delta$ 5.10 (1H, brs), 5.06 (1H, brs), $4.11(2 \mathrm{H}, \mathrm{m}), 2.14(1 \mathrm{H}, \mathrm{dt}, J=14.0,3.8 \mathrm{~Hz}), 1.96(1 \mathrm{H}, \mathrm{m}), 1.86$ $(2 \mathrm{H}, \mathrm{m}), 1.63(3 \mathrm{H}, \mathrm{m}), 1.23(3 \mathrm{H}, \mathrm{t}, J=7.1 \mathrm{~Hz}), 1.12(1 \mathrm{H}, \mathrm{m}), 0.75(1 \mathrm{H}, \mathrm{dd}, J=6.1,3.5 \mathrm{~Hz}) ;{ }^{13} \mathrm{C}$ NMR $\delta 174.0,143.3,114.8,60.6,32.6,27.4,23.4,22.5,20.4,19.9,14.2$; HRMS (ESI): for $\mathrm{C}_{11} \mathrm{H}_{16} \mathrm{O}_{2}$ calcd $180.1150[\mathrm{M}]^{+}$; found 180.1149 .

4,4a,5,6-Tetrahydro-1H-cyclopropa[1,6]benzo[1,2-c]furan-3-one (12). A solution of 11 (1.48 $\mathrm{g}, 8.20 \mathrm{mmol})$ in $\mathrm{CH}_{2} \mathrm{Cl}_{2}(10 \mathrm{ml})$ was added dropwise to a stirred solution of $\mathrm{m}$-CPBA $(2.40 \mathrm{~g}$, $9.90 \mathrm{mmol}, 70-75 \%$ in $\left.\mathrm{H}_{2} \mathrm{O}\right)$ and $\mathrm{NaHCO}_{3}(1.00 \mathrm{~g}, 12.3 \mathrm{mmol})$ in $\mathrm{CH}_{2} \mathrm{Cl}_{2}(40 \mathrm{ml})$ at $0^{\circ} \mathrm{C}$. Stirring was continued for $3 \mathrm{~h}$. The mixture was washed with $1 \%$ aqueous $\mathrm{Na}_{2} \mathrm{SO}_{3}(2 \times 25 \mathrm{ml})$, $5 \%$ aqueous $\mathrm{NaHCO}_{3}(2 \times 25 \mathrm{ml})$ and with water until neutral. The organic layer was dried with $\mathrm{Na}_{2} \mathrm{SO}_{4}$, filtered and concentrated to afford the crude epoxide, which was used directly without further purification. The epoxide was refluxed in $\mathrm{CHCl}_{3}(50 \mathrm{ml})$ with a catalytic amount $p$-TsOH for $3 \mathrm{~h}$. After cooling, the mixture was washed twice with water, dried, concentrated and chromatographed to give 12 (0.53 g, $3.55 \mathrm{mmol}, 43 \%):{ }^{1} \mathrm{H}$ NMR (400 MHz) $\delta 5.45(1 \mathrm{H}, \mathrm{m})$, $4.99(1 \mathrm{H}$, dddd, $J=12.9,4.4,2.5,0.9 \mathrm{~Hz}), 4.91(1 \mathrm{H}, \mathrm{m}), 2.22(1 \mathrm{H}, \mathrm{m}), 2.12(1 \mathrm{H}, \mathrm{m}), 2.03(1 \mathrm{H}$, $\mathrm{dd}, J=13.5,6.6 \mathrm{~Hz}), 1.75(1 \mathrm{H}, \mathrm{m}), 1.53(1 \mathrm{H}, \mathrm{dd}, J=8.6,4.3 \mathrm{~Hz}), 1.48(1 \mathrm{H}, \mathrm{dd}, J=6.6,4.3 \mathrm{~Hz})$, $1.38(1 \mathrm{H}, \mathrm{m}) ;{ }^{13} \mathrm{C}$ NMR $\delta 178.8,134.2,113.2,70.2,24.3,23.5,19.1,19.0,18.0$; HRMS (FAB): for $\mathrm{C}_{9} \mathrm{H}_{11} \mathrm{O}_{2}$ calcd $151.0759[\mathrm{M}+\mathrm{H}]^{+}$; found 151.0757 .

5-Methoxytetrahydro-1aH-cyclopropa[d]oxireno[h][2]benzofuran (13). A $1.2 \mathrm{M}$ solution of DIBAL-H $(3.3 \mathrm{ml})$ in toluene was added very slowly to a solution of $12(0.59 \mathrm{~g}, 3.93 \mathrm{mmol})$ in toluene $(10 \mathrm{ml})$ at $-78^{\circ} \mathrm{C}$. A saturated aqueous solution of potassium sodium tartrate $(5 \mathrm{ml})$ was added to the reaction at $-78^{\circ} \mathrm{C}$ after $3 \mathrm{~h}$. The mixture was allowed to warm to room temperature and then extracted with EtOAc. The combined extracts were dried, filtered and concentrated to afford the crude lactol, which was used directly without further purification. To a solution of the lactol in pentane/MeOH $(9: 1,50 \mathrm{ml})$ was added a catalytic amount of $p$-TsOH. A saturated aqueous solution of $\mathrm{NaHCO}_{3}$ was added after $10 \mathrm{~min}$ and the organic phase was separated. The aqueous phase was extracted with $\mathrm{Et}_{2} \mathrm{O}$. The combined organic extracts were dried with $\mathrm{Na}_{2} \mathrm{SO}_{4}$ and concentrated to afford an epimeric mixture (10:7) of crude methyl-acetal, which was used 
directly without further purification. To a solution of the crude acetal in acetone $(10 \mathrm{ml})$ was added a solution of dimethyldioxirane $\left(3.9 \mathrm{mmol}, 65 \mathrm{ml}, \sim 0.06 \mathrm{M}\right.$ in acetone) at $0^{\circ} \mathrm{C}$. The solvent was removed after $1 \mathrm{~h}$ and the residue was re-dissolved in $\mathrm{Et}_{2} \mathrm{O}$, dried with $\mathrm{Na}_{2} \mathrm{SO}_{4}$, concentrated and chromatographed on $\mathrm{Al}_{2} \mathrm{O}_{3}$ (neutral, activity II-III) to give an epimeric mixture (10:7) of 13 (0.13 g, mmol, 18\%): ${ }^{1} \mathrm{H}$ NMR $\left(500 \mathrm{MHz}, \mathrm{C}_{6} \mathrm{D}_{6}\right) \delta$ major $4.67(1 \mathrm{H}, \mathrm{s}), 4.14(1 \mathrm{H}, \mathrm{d}, J=11.9 \mathrm{~Hz})$, $4.12(1 \mathrm{H}, \mathrm{d}, J=11.9 \mathrm{~Hz}), 3.25(3 \mathrm{H}, \mathrm{s}), 2.78(1 \mathrm{H}, \mathrm{t}, J=2.9 \mathrm{~Hz}), 1.59(1 \mathrm{H}, \mathrm{m}), 1.57(1 \mathrm{H}, \mathrm{m}), 1.39$ $(1 \mathrm{H}, \mathrm{m}), 1.23(1 \mathrm{H}, \mathrm{m}), 1.11(1 \mathrm{H}, \mathrm{m}), 0.75(1 \mathrm{H}, \mathrm{m}), 0.64(1 \mathrm{H}, \mathrm{dd}, J=8.6,4.6 \mathrm{~Hz})$; minor 4.65 $(1 \mathrm{H}, \mathrm{s}), 4.33(1 \mathrm{H}, \mathrm{d}, J=9.5 \mathrm{~Hz}), 3.83(1 \mathrm{H}, \mathrm{d}, J=9.5 \mathrm{~Hz}), 3.32(3 \mathrm{H}, \mathrm{s}), 2.66(1 \mathrm{H}, \mathrm{dd}, J=5.4,2.8$ $\mathrm{Hz}), 1.47(1 \mathrm{H}, \mathrm{m}), 1.38(1 \mathrm{H}, \mathrm{m}), 1.29(1 \mathrm{H}, \mathrm{m}), 1.12(1 \mathrm{H}, \mathrm{m}), 0.90(1 \mathrm{H}, \mathrm{m}), 0.84(1 \mathrm{H}, \mathrm{m}), 0.76$ $(1 \mathrm{H}, \mathrm{m}) ;{ }^{13} \mathrm{C}$ NMR $\delta$ major 108.8, 68.6, 62.9, 53.9, 52.9, 26.5, 22.1, 18.9, 12.8, 9.1; minor 108.6, 67.9, 62.2, 53.9, 52.3, 26.7, 20.7, 18.9, 13.7, 8.0; HRMS (ESI): for $\mathrm{C}_{10} \mathrm{H}_{14} \mathrm{O}_{3}$ calcd 182.0943 $[\mathrm{M}]^{+}$; found 182.0942 .

3-Methoxy-4a,5,6,7-tetrahydro-4H-cyclopropa[1,6]benzo[1,2-c]furan-7-ol (4). $n$-BuLi (0.61 $\mathrm{ml}, 1.51 \mathrm{mmol}, 2.5 \mathrm{M}$ in hexane) was added to a solution of diisopropyl amine $(0.21 \mathrm{ml}, 1.51$ $\mathrm{mmol})$ in THF $(10 \mathrm{ml})$ at $-78^{\circ} \mathrm{C}$. After $0.5 \mathrm{~h} 13(0.13 \mathrm{~g}, 0.72 \mathrm{mmol})$ in THF $(5 \mathrm{ml})$ was added drop wise to the solution at $-78^{\circ} \mathrm{C}$. The reaction mixture was allowed to equilibrate to room temperature. A saturated aqueous solution of $\mathrm{NaHCO}_{3}(5 \mathrm{ml})$ was added after $4 \mathrm{~h}$. The organic layer was separated and the aqueous layer was extracted with $\mathrm{Et}_{2} \mathrm{O}(10 \mathrm{ml})$. The combined organic fractions were dried with $\mathrm{Na}_{2} \mathrm{SO}_{4}$, concentrated and chromatographed on $\mathrm{Al}_{2} \mathrm{O}_{3}$ (neutral, activity II-III) to give 4 as an epimeric mixture (10:7) (0.08 g, $0.43 \mathrm{mmol}, 60 \%):{ }^{1} \mathrm{H}$ NMR (500 $\left.\mathrm{MHz}, \mathrm{C}_{6} \mathrm{D}_{6}\right) \delta 5.07(1 \mathrm{H}, \mathrm{s}), 6.40(1 \mathrm{H}, \mathrm{s}), 4.24(1 \mathrm{H}, \mathrm{t}, J=5.1 \mathrm{~Hz}), 3.25(3 \mathrm{H}, \mathrm{s}), 1.74(2 \mathrm{H}, \mathrm{m}), 1.71$ $(1 \mathrm{H}, \mathrm{m}), 1.48(1 \mathrm{H}, \mathrm{d}, J=5.7 \mathrm{~Hz}), 1.46(1 \mathrm{H}, \mathrm{d}, J=5.7 \mathrm{~Hz}), 1.12(1 \mathrm{H}, \mathrm{t}, J=4.4 \mathrm{~Hz}), 0.72(1 \mathrm{H}, \mathrm{dd}$, $J=8.7,4.4 \mathrm{~Hz}) ;{ }^{13} \mathrm{C}$ NMR $\delta$ 140.2, 118.0, 110.7, 62.8, 54.3, 31.4, 30.6, 20.9, 20.5, 14.2; HRMS (FAB): for $\mathrm{C}_{10} \mathrm{H}_{14} \mathrm{O}_{3}$ calcd $182.0943[\mathrm{M}]^{+}$; found 182.0939 .

Ethyl 2-oxooctahydrocyclopropa[e]indene-1a(1H)-carboxylate (15) was prepared according to the procedure described for $\mathbf{1 1}$ using $\alpha, \beta$-unsaturated $\beta$-keto ester $\mathbf{1 4}$ (prepared according to reference 7) as starting material. Chromatography afforded 15 (2.4 g, $10.8 \mathrm{mmol}, 69 \%):{ }^{1} \mathrm{H}$ NMR $(300 \mathrm{MHz}) \delta 4.18(2 \mathrm{H}, \mathrm{q}, J=7.1 \mathrm{~Hz}), 2.37(1 \mathrm{H}, \mathrm{q}, J=7.4 \mathrm{~Hz}), 2.25(1 \mathrm{H}, \mathrm{dd}, J=15.1,4.6$ $\mathrm{Hz}), 2.15(1 \mathrm{H}, \mathrm{m}), 2.08(1 \mathrm{H}, \mathrm{m}), 2.02(1 \mathrm{H}, \mathrm{m}), 1.87(2 \mathrm{H}, \mathrm{brs}), 1.75(2 \mathrm{H}, \mathrm{m}), 1.65(2 \mathrm{H}, \mathrm{m}), 1.40$ $(1 \mathrm{H}, \mathrm{m}), 1.25(3 \mathrm{H}, \mathrm{t}, J=7.1 \mathrm{~Hz}), 1.18(1 \mathrm{H}, \mathrm{brs}) ;{ }^{13} \mathrm{C} \mathrm{NMR} \delta 204.4,170.7,61.8,40.4,37.7,36.3$, 35.4, 31.8, 31.4, 31.2, 22.5, 20.3, 14.5; HRMS (FAB): for $\mathrm{C}_{13} \mathrm{H}_{19} \mathrm{O}_{3}$ calcd 223.1334 [M+H] ${ }^{+}$; found 223.1336 .

Ethyl 2-methyleneoctahydrocyclopropa[e]indene-1a(1H)-carboxylate (16) was prepared and purified according to the procedure described for $\mathbf{1 1}$ using $\beta$-keto ester $\mathbf{1 5}$ as starting material. The reaction afforded 16 (1.52 g, $6.90 \mathrm{mmol}, 69 \%):{ }^{1} \mathrm{H}$ NMR (400 MHz) $\delta 5.09(2 \mathrm{H}, \mathrm{m}), 4.12$ $(2 \mathrm{H}, \mathrm{m}), 4.10(2 \mathrm{H}, \mathrm{m}), 2.19(1 \mathrm{H}, \mathrm{m}), 1.91(2 \mathrm{H}, \mathrm{m}), 1.89(1 \mathrm{H}, \mathrm{m}), 1.72(1 \mathrm{H}, \mathrm{m}), 1.71(1 \mathrm{H}, \mathrm{dd}, J=$ 9.6, $4.1 \mathrm{~Hz}), 1.70(1 \mathrm{H}, \mathrm{m}), 1.52(4 \mathrm{H}, \mathrm{m}), 1.40(1 \mathrm{H}, \mathrm{m}), 1.23(3 \mathrm{H}, \mathrm{t}, J=7.1 \mathrm{~Hz}), 0.72(1 \mathrm{H}, \mathrm{dd}, J=$ 7.0, 4.1 Hz); ${ }^{13} \mathrm{C}$ NMR $\delta 174.1,143.7,114.4,60.6,37.8,36.9,35.3,31.6,31.4,28.0,27.7,22.6$, 22.4, 14.2; HRMS (FAB): for $\mathrm{C}_{14} \mathrm{H}_{21} \mathrm{O}_{2}$ calcd $221.1542[\mathrm{M}+\mathrm{H}]^{+}$; found 221.1543. 
1,4,5a,6,7,8,8a,8b-octahydrocyclopropa[4,5]indeno[5,6-c]furan-2-one (17). To a solution of alkene $16(1.10 \mathrm{~g}, 5.00 \mathrm{mmol})$ in acetone $(10 \mathrm{ml})$ was added a solution of dimethyldioxirane (55 $\mathrm{ml}, \sim 0.10 \mathrm{M}$ in acetone) at $0^{\circ} \mathrm{C}$. The solvent was removed after $1 \mathrm{~h}$ and the residue was redissolved in $\mathrm{Et}_{2} \mathrm{O}$, dried with $\mathrm{Na}_{2} \mathrm{SO}_{4}$ and concentrated to afford the crude epoxide, which was used directly without further purification. The epoxide was refluxed in $\mathrm{CHCl}_{3}(50 \mathrm{ml})$ with a catalytic amount $p$-TsOH for $3 \mathrm{~h}$. After cooling, the mixture was washed twice with water, dried, concentrated and chromatographed to give $17(0.75 \mathrm{~g}, 3.9 \mathrm{mmol}, 79 \%)$ and unreacted $16(0.08 \mathrm{~g}$, $0.38 \mathrm{mmol}, 8 \%$ ) was recovered: ${ }^{1} \mathrm{H}$ NMR $(400 \mathrm{MHz}) \delta 5.00(1 \mathrm{H}, \mathrm{m}), 4.96(1 \mathrm{H}, \mathrm{m}), 4.91(1 \mathrm{H}, \mathrm{dt}$, $J=12.4,2.2 \mathrm{~Hz}), 2.44(1 \mathrm{H}, \mathrm{m}), 2.39$ (1H, m), 2.18 (1H, dd, $J=8.4,7.0 \mathrm{~Hz}), 1.84$ (1H, m), 1.77 $(1 \mathrm{H}, \mathrm{m}), 1.60(1 \mathrm{H}, \mathrm{m}), 1.58(2 \mathrm{H}, \mathrm{m}), 1.57(1 \mathrm{H}, \mathrm{m}), 1.33(1 \mathrm{H}, \mathrm{dd}, J=6.7,3.9 \mathrm{~Hz}), 1.19(1 \mathrm{H}, \mathrm{m})$; ${ }^{13} \mathrm{C}$ NMR $\delta 178.8,133.3,118.0,70.1,36.7,36.1,32.4,29.7,26.5,23.9,23.1,23.0$; HRMS (ESI): for $\mathrm{C}_{12} \mathrm{H}_{14} \mathrm{O}_{2}$ calcd $190.0994[\mathrm{M}]^{+}$; found 190.0991 .

2-Methoxy-1,4,5a,6,7,8,8a,8b-octahydrocyclopropa[4,5]indeno[5,6-c]furan (18). A $1.2 \mathrm{M}$ solution of DIBAL-H $(3.4 \mathrm{ml})$ in toluene was added very slowly to a solution of $\mathbf{1 7}(0.74 \mathrm{~g}, 3.91$ $\mathrm{mmol})$ in toluene $(25 \mathrm{ml})$ at $-78^{\circ} \mathrm{C}$. A saturated aqueous solution of potassium sodium tartrate $(5$ $\mathrm{ml}$ ) was added to the reaction, at $-78^{\circ} \mathrm{C}$, after $3 \mathrm{~h}$. The mixture was allowed to warm to room temperature and was then extracted with EtOAc. The combined extracts were dried and concentrated to afford the crude lactol, as a mixture of lactol/aldehyde-alcohol and lactol epimers, which was used directly without further purification. A catalytic amount of $p$-TsOH was added to a solution of the lactol in pentane/ $\mathrm{MeOH}(9: 1,50 \mathrm{ml})$. A saturated aqueous solution of $\mathrm{NaHCO}_{3}$ was added after $10 \mathrm{~min}$ and the organic phase was separated. The aqueous phase was extracted with $\mathrm{Et}_{2} \mathrm{O}$. The combined organic extracts were dried with $\mathrm{Na}_{2} \mathrm{SO}_{4}$, concentrated and chromatographed to give $18(0.43 \mathrm{~g}, 2.10 \mathrm{mmol}, 53 \%)$ as an epimeric mixture (3:1): ${ }^{1} \mathrm{H}$ NMR $\left(400 \mathrm{MHz}, \mathrm{C}_{6} \mathrm{D}_{6}\right) \delta$ major $4.66(1 \mathrm{H}, \mathrm{s}), 4.57(1 \mathrm{H}, \mathrm{m}), 4.26(1 \mathrm{H}, \mathrm{m}), 3.24(3 \mathrm{H}, \mathrm{s}), 2.18(2 \mathrm{H}, \mathrm{m})$, $1.65(2 \mathrm{H}, \mathrm{m}), 1.63(1 \mathrm{H}, \mathrm{m}), 1.60(2 \mathrm{H}, \mathrm{m}), 1.59(1 \mathrm{H}, \mathrm{m}), 1.49(1 \mathrm{H}, \mathrm{m}), 1.36(1 \mathrm{H}, \mathrm{m}), 0.85(1 \mathrm{H}$, $\mathrm{dd}, J=8.5,4.1 \mathrm{~Hz}), 0.73(1 \mathrm{H}, \mathrm{dd}, J=5.8,4.1 \mathrm{~Hz}) ;{ }^{13} \mathrm{C}$ NMR $\delta$ major $141.2,115.3,109.8,70.2$, 54.7, 38.3, 38.0, 33.8, 30.8, 24.2, 22.7, 20.6, 19.7; HRMS (FAB): for $\mathrm{C}_{13} \mathrm{H}_{19} \mathrm{O}_{2}$ calcd 207.1385 $[\mathrm{M}+\mathrm{H}]^{+}$; found 207.1383 .

2-Methoxy-1,5,5a,6,7,8,8a,8b-octahydrocyclopropa[4,5]indeno[5,6-c]furan-5-ol (5). To a solution of acetal $18(0.43 \mathrm{~g}, 2.06 \mathrm{mmol})$ in acetone $(10 \mathrm{ml})$ was added a solution of dimethyldioxirane $(2.4 \mathrm{mmol}, 48 \mathrm{ml}, \sim 0.05 \mathrm{M}$ in acetone $)$ at $0^{\circ} \mathrm{C}$. The solvent was removed after $1 \mathrm{~h}$ and the residue was re-dissolved in $\mathrm{Et}_{2} \mathrm{O}$, dried with $\mathrm{Na}_{2} \mathrm{SO}_{4}$ and concentrated to afford the crude epoxide, which was used directly without further purification. $t$-BuLi (1.56 ml, $2.34 \mathrm{mmol}$, $1.5 \mathrm{M}$ in pentane) was added to a solution of diisopropyl amine $(0.26 \mathrm{ml}, 1.82 \mathrm{mmol})$ in THF (5 $\mathrm{ml})$ at $-78^{\circ} \mathrm{C}$. The crude epoxide $(0.25 \mathrm{~g})$ dissolved in THF $(1 \mathrm{ml})$ was added dropwise to the solution during $0.5 \mathrm{~h}$ at $-78^{\circ} \mathrm{C}$. The reaction mixture was allowed to reach room temperature. A saturated aqueous solution of $\mathrm{NaHCO}_{3}$ (sat) $(5 \mathrm{ml})$ was added after $2 \mathrm{~h}$. The organic layer was separated and the aqueous layer was extracted with $\mathrm{Et}_{2} \mathrm{O}(10 \mathrm{ml})$. All organic fraction were dried with $\mathrm{Na}_{2} \mathrm{SO}_{4}$, concentrated and chromatographed on $\mathrm{Al}_{2} \mathrm{O}_{3}$ (neutral, activity II-III) to give 5 as an epimeric mixture (3:1) (0.17 g, $0.74 \mathrm{mmol}, 63 \%):{ }^{1} \mathrm{H} \mathrm{NMR}\left(500 \mathrm{MHz}, \mathrm{C}_{6} \mathrm{D}_{6}\right) \delta 6.29(1 \mathrm{H}, \mathrm{s})$, 
$4.96(1 \mathrm{H}, \mathrm{s}), 4.00(1 \mathrm{H}, \mathrm{d}, J=3.0 \mathrm{~Hz}), 3.19(3 \mathrm{H}, \mathrm{s}), 2.37(1 \mathrm{H}, \mathrm{dt}, J=6.5,3.0 \mathrm{~Hz}), 2.05(1 \mathrm{H}, \mathrm{m})$, $1.78(1 \mathrm{H}, \mathrm{m}), 1.71(1 \mathrm{H}, \mathrm{m}), 1.61(1 \mathrm{H}, \mathrm{m}), 1.46(1 \mathrm{H}, \mathrm{m}), 1.45(1 \mathrm{H}, \mathrm{m}), 1.27(1 \mathrm{H}, \mathrm{m}), 1.26(1 \mathrm{H}$, $\mathrm{m}), 1.23(1 \mathrm{H}, \mathrm{m}), 0.71(1 \mathrm{H}, \mathrm{dd}, J=11.4,6.1 \mathrm{~Hz}) ;{ }^{13} \mathrm{C}$ NMR $\delta 140.4,115.2,111.1,65.8,55.4$, 46.6, 36.8, 36.4, 32.3, 28.8, 24.2, 20.8, 19.9; HRMS (FAB): for $\mathrm{C}_{13} \mathrm{H}_{18} \mathrm{O}_{3}$ calcd 222.1256 [M] ${ }^{+}$; found 222.1252 .

\section{References}

1. Sterner, O.; Bergman, R.; Kihlberg J.; Wickberg B. J. Nat. Prod. 1985, 48, 279.

2. Sterner, O.; Bergman, R.; Kesler, E.; Nilsson, L.; Oluwadiya, J.; Wickberg, B. Tetrahedron Lett. 1983, 24, 1415.

3. Hansson, T.; Sterner, O. Tetrahedron Lett. 1991, 32, 2541.

4. Hansson, T.; Pang, Z.; Sterner, O. Acta Chem. Scand. 1993, 47, 403.

5. Bocchio, F.; Kalf-Hansen, S.; Dekermendjian, K.; Sterner, O.; Witt, R. Tetrahedron Lett. 1992, 33, 6867.

6. Gustafsson, J.; Sterner, O. Tetrahedron 1995, 51, 3865.

7. I. Aujard, I.; Röme, D.; Arzel, E.; Johansson, M.; de Vos, D.; Sterner, O. Bioorg. Med. Chem. 2005, 13, 6145.

8. Mori K.; Mori, H. Tetrahedron 1986, 42, 5531.

9. (a) Corey, E. J.; Chaykovsky, M. J. Am. Chem. Soc. 1965, 87, 1353. (b) Cativiela, C.; Díazde-Villegas, M. D.; Jiménez, A. I. Tetrahedron 1994, 50, 9157.

10. (a) Liapis, M.; Ragoussis, N.; Ragoussis, V. J. Chem. Soc., Perkin Trans. I, 1985, 815. (b) Yang, M. S.; Chang, S. Y.; Lu, S. S.; Rao, P. D.; Liao, C. C. Synlett 1999, 225.

11. Thompson, S. C.; Heathcock, C. H. J. Org. Chem. 1992, 57, 5979.

12. (a) Adam, W.; J. Bialas, J.; Hadjiarapoglou, L.; Chem. Ber. 1991, 124, 2377. (b) Adam, W.; Chen, Y.; Cremer, D.; Gauss, J.; Scheutzow, D.; Schindler, M. J. Org. Chem. 1987, 52, 2800 .

13. Bittman, R.; Boswell, G. A.; Danishefsky, S.; Gschwend, H. W.; Heck, R. F.; Hirchmann, R. F.; Paquette, L. A.; Posner, G. H.; Reich, H. J.; Weinstein, B. Org. Reac. 1983, 29. 